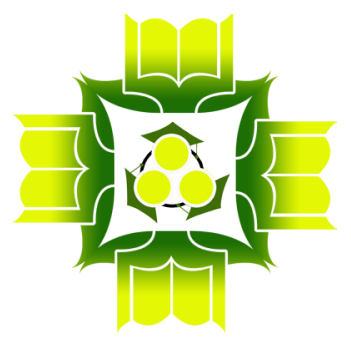

\title{
IMPLEMENTATION OF MULTICULTURAL EDUCATION IN GROWING TOLERANCE BETWEEN STUDENTS IN STATE ELEMENTARY SCHOOL 2 KOMET BANJARBARU
}

\author{
Barsihanor \\ Muhammad Arsyad Al-Banjari Banjarmasin Universitas Islam Kalimantan \\ barsihanor@uniska-bjm.ac.id \\ Abdul Hafiz \\ Muhammad Arsyad Al-Banjari Banjarmasin Universitas Islam Kalimantan \\ abdulhafiz@uniska-bjm.ac.id \\ Muhammad Iqbal Ansari \\ Muhammad Arsyad Al-Banjari Banjarmasin Universitas Islam Kalimantan \\ muhammadiqbalansari13@gmail.com \\ Galuh Nashrulloh Kartika Mayangsari Rofam \\ Muhammad Arsyad Al-Banjari Banjarmasin Universitas Islam Kalimantan \\ galuh.nashrulloh@uniska-bjm.ac.id

\section{Siti Liani} \\ Universitas Islam Negeri Antasari Banjarmasin \\ Sitiliani16@gmail.com

\section{Shalahudin} \\ Universitas Islam Negeri Sulthan Thaha Saifuddin Jambi \\ sholahuddin@uinjambi.ac.id
}

\begin{abstract}
Indonesia is a plural country with various ethnic groups, languages, religion, and culture. This is prone to friction such as conflicts between ethnicities, religion, and so on. This study aimed to know the implementation of multicultural education in growing tolerance between students in state Elementary School 2 Komet Banjarbaru. This study used qualitative approach with case study type of research. The study was done from
\end{abstract}


January 2020 until March 2020. Data was collected by in-depth interview, participant observation, and documentation technique. The informants in this study were 11 samples including the headmaster, teacher, and students. After obtaining the data, analysis was done through the series of reduction, display, and data verification. Meanwhile, validity test was done by triangulation. The result showed that the implementation of multicultural education in growing tolerance between students in state Elementary School 2 Komet Banjarbaru through the school policy regulating that the rights of every student is equal, no obligation for non-Muslim female students to wear hijab, no obligation for non-Muslim students to attend Islamic religious activities, and religion subjects are customized to each religion, Muslim students learn Islamic studies, while non-Muslim students learn about their own religion, and they are free to learn religion studies in their own house of worship.

Keywords: Multicultural Education, Elementary School, Tolerance.

\begin{abstract}
Abstrak
Indonesia adalah negara yang majemuk dengan berbagai suku, bahasa, agama, dan budaya. Hal ini rawan terjadi gesekan seperti konflik antar suku, agama, dan sebagainya. Penelitian ini bertujuan untuk mengetahui implementasi pendidikan multikultural dalam menumbuhkan toleransi antar siswa di SDN 2 Komet Banjarbaru. Penelitian ini menggunakan pendekatan kualitatif dengan jenis penelitian studi kasus. Penelitian dilakukan pada bulan Januari 2020 hingga Maret 2020. Pengumpulan data dilakukan dengan wawancara mendalam, observasi partisipan, dan teknik dokumentasi. Informan dalam penelitian ini berjumlah 11 sampel yang meliputi kepala sekolah, guru, dan siswa. Setelah data diperoleh, analisis dilakukan melalui rangkaian reduksi, display, dan verifikasi data. Sedangkan uji validitas dilakukan dengan triangulasi. Hasil penelitian menunjukkan bahwa pelaksanaan pendidikan multikultural dalam menumbuhkan toleransi antar siswa di SDN 2 Komet Banjarbaru melalui kebijakan sekolah yang mengatur bahwa hak setiap siswa adalah sama, tidak ada kewajiban bagi siswi non muslim berhijab, tidak ada kewajiban untuk mahasiswa nonmuslim untuk mengikuti kegiatan keagamaan islam, dan mata pelajaran agama disesuaikan dengan agama masing-masing, santri muslim belajar ilmu agama islam, sedangkan santri non muslim belajar agamanya sendiri, dan mereka bebas belajar ilmu agama di rumah ibadahnya masing-masing.
\end{abstract}

Kata Kunci: Pendidikan Multikultural, Sekolah Dasar, Toleransi. 


\section{INTRODUCTION}

Indonesia is a nation and country whose culture, ethnicity, tradition, religion, and languages are various (Suprapti, 2018). Those differences are the challenge to reach the education goal (Ibrahim, 2013). On one hand, the diversities and culture differences could be a gift and wealth with high value for Indonesia. Thus, the people life become more dynamic, colourful, not boring, and complement to each other's. In other word, plurality enriches the life and becomes the essence of society life (Suprapti, 2018).

In education strategy frame of a plural country, culture-based education urges the construction process of imaginative, metaphoric, creative, and awareness of culture. However, the use of local culture (ethnic) in culture-based education cannot be separated from the various cases occurred in every component of education from the early preparation to the implementation. Some of the early cases in culture-based education on early preparation stage are: (Faiqoh, 2015)

1. Teacher does not really understand his own culture, local culture, or students' culture.

2. Teacher does not really understand the students' ethnic structure and culture, especially in the context of subject he teaches.

3. The lack of teacher expertise in preparing equipment that can trigger attention, memory, and reintroduction of the cultural treasures to the students in each context and learning experience.

Principally, multicultural education is an education that appreciates diversity. Hence, the diversities here would not result on the emerge of conflict and disunity. This mutual tolerance is what makes the diversity dynamic and the cultural wealth as the nation's identity worthy to preserve. The typical cultural characteristics can be observed from Indonesians which consist of various ethnic groups. Every ethnic group has its own unique territory (Kholik, 2017).

On the other hand, the diversity has a prone effect to emerge social conflict that threatens the unity of the nation, such as enmity and conflict between religions, hatred of other culture, and even war. Various conflicts related to SARA (ethnic, religion, race, and inter-group) usually occur in this country, such as conflict 
between the Madurese and the Dayak tribes in West Kalimantan, fights between the Makassar people and the indigenous Timorese which then developed into friction between Catholics and Islam, between Tionghoa and indigenous and so on. The failure to maintain tolerance would affect the emerge of conflicts like what happened in Tolikara regency where there was a burning of a mosque by Christians ahead of the Eid prayer. Similar case was occurred in Aceh, Singkel regency, on Tuesday October $13^{\text {th }}$ in 2015 where the people were dissatisfied with the local government agreement with the people about 21 churches with problematic permission, which then hundreds of masses moved toward the churches by motorcycles and pickup trucks, and they burned them.

The incident that occurred in Singkel was caused by the displeasure of Muslims towards the ways in which Christians developed their teachings. In addition, the attitude of Christians is considered by Muslims to be less respectful of their existence, such as building churches without permission, releasing pigs, and bringing their meat into the midst of the Muslim community. Some of the adherents of Islam responded strongly to the actions of these Christians. The attitude of Christians is considered by Muslims to be less respectful of their existence by doing so. Actually, religious conflict can be caused by various things, it can be in the form of differences in doctrine and attitudes, ethnic and racial differences, cultural differences, as well as majority and minority problems (Sujarwanto, 2012).

These conflicts occur because of the lack of understanding of the existing cultural diversity individually or in group. The conflicts that occur indicate that the Indonesian population does not yet have a broad insight into the cultural plurality that exists in this country. Therefore, it is necessary to have a deep understanding of mutual respect between various ethnic groups, races, groups, customs, and religions.

Based on the above reality, multicultural education is an alternative solution that can be applied. Multicultural education is education that provides recognition, appreciation, and respect for differences in equality, including language, race, ethnicity, culture, and religion. (Mansur, 2016). Through the provision of knowledge about the diversity, it is expected that students will have awareness that the existence of diversity in this world would not prevent 
them to work together and interact with each other (Dewi et al., 2020), and also multicultural education could be a strategic way in growing nationalism for students (Furqon, 2020). Multicultural education has at least four elements, which are equality, tolerance, democracy, and pluralism (Amin, 2018). In line with it, Baharun and Awwaliyah (2017) stated that the concept of multicultural education included the concept of similarity, pluralism, democracy, and freedom.

In the context of Indonesia that full of pluralism, multicultural education has important role to manage the diversity in education because education cannot be separated from society context. Therefore, the implementation of multicultural education in Indonesia is very applicable, seen from the existed diversity, for the sake of unity (Nurcahyono, 2018).

Various size of diversity of Indonesian culture may cause some problems in education, especially in a class whose students are from different ethnic groups: (Faiqoh, 2015)

1. Content selection and integration of subject material

2. The knowledge construction process

3. Prejudice reduction

4. Equity pedagogy

The implementation of multicultural education is not always about changing the curriculum. Learning in multicultural education can be integrated in every subject. However, a guide for teachers is needed to implement it, especially to teach tolerance, togetherness, human rights, democracy, and mutual respect to the students. Those are very valuable as a provision for them in the future and very important to uphold human values. Schools play an important role in cultivating multicultural values in students from an early age. The role of the teacher to support the character of students to maintain culture (Rahayuningtyas et al., 2021). Children as the center of attention in education whose interests are often forgotten are part of the social context. They have different social and cultural contexts from each other (Arifudin, 2007).

Elementary School (SD) or Madrasah Ibtidaiyah (MI) is a formal institution that lays the foundation for education for the higher school level. On one hand, 
elementary school has the responsibility to develop students into potential young generation with high knowledge of the nation's cultural diversity. On the other hand, elementary schools also have the responsibility to shape students into a generation that is tolerant, capable, and willing to act to appreciate the differences that exist amid the nation's cultural pluralism. To achieve the tasks and responsibilities in these elementary schools, one way that can be done is to apply multicultural-based learning in elementary schools. Cultural literacy and citizenship is the right solution to hone and develop social skills for elementary school students (Ahsani \& Azizah, 2021).

If from the beginning they already have the values of togetherness, tolerance, love of peace, and respect for differences, then these values will be reflected in their daily behavior because they have become characters in themselves. If this is successfully owned by the young generation of this nation, then the future life can be predicted to be relatively peaceful and respect between others is fully realized. Therefore, attention from school, in this case teachers, is not only demanded to professionally implement the multicultural values in every opportunity and subject at school, but they are also responsible to instill the values of diversity in students. In addition, parental and community involvement is also needed to maximize the implementation of multicultural education properly (Munajah et al., 2020).

Based on interview result, State Elementary School 2 Komet Banjarbaru is one of the elementary schools whose students are not only Muslims, but there are also some Protestants and Catholics. In addition, State Elementary School 2 Komet Banjarbaru has students from different areas and ethnicities in Kalimantan and outside of Kalimantan, such as Java and Sulawesi. On economy aspect, students' parents come from various social status background, i.e. farmer, laborers, entrepreneurs, and civil servants (Syakrani, personal communication, January 20, 2020)

State Elementary School 2 Komet Banjarbaru is one of the elementary schools that applies multicultural education concept, this approach can build tolerance and solidarity among diverse beliefs, social status, ethnic groups, and intelligence level. Moreover, students will respect others with different belief, social status, ethnic group, and intelligence level. This phenomenon shows us 
that we need to know the implementation of multicultural education in growing tolerance among students in State Elementary School 2 Komet Banjarbaru.

\section{METHODS}

The study of implementation of multicultural education in State Elementary School 2 Komet Banjarbaru used qualitative approach, which was a study that aimed to understand holistically the phenomenon about what happened on the subject, such as behavior, perception, action, motivation, and so on, by describing it into language and words on specific scientific context in any scientific method (Moleong, 2012).

The type of this study was case study. The case that has been studied in this study was the implementation of inclusive education in State Elementary School 2 Komet Banjarbaru. The study was done in January to March 2020. The informants in this study were 11 samples including the headmaster, teacher, and students. On data collection process, researcher used many methods, to support and complete each method to another ones. The purpose was to get data holistically, valid, and reliable, based on the main problem. The methods used were observation, interview, and documentation.

Validity check or test in this study was using triangulation of source and techniques, by comparing data obtained by researcher from the informants and the ones obtained from interview, observation, and documentation result. For the data analysis, it was carried out before entering the field, while in the field and after finishing from the field. It was in line with Miles and Huberman stated that qualitative studies were carried out when data collection was in progress until after the completion of data collection within a certain period. Data analysis on qualitative study was done interactively and continuously until it was finished and completed, so that the data was already saturated. It means that the data or information was real and as it was.

\section{RESULTS AND DISCUSSION}

State Elementary School 2 Komet Banjarbaru implemented multicultural education by integrating in learning process. The learning process always upholds dignity, freedom of thought and expression, regardless of religion, 
ethnicity, race, and other differences. Teachers do not differentiate in providing services and learning to students. It corresponded to Makassary and Suparto who stated that multicultural education gave equal opportunities for all students from different race, ethnic group, social level, and cultural groups to get education (Almakasasary, 2010). Multicultural education prioritizes the equal rights and dignity of students as human beings. It is in line with Paulo Freire's argumentation that learning was not an ivory tower to prevent social and cultural reality. Learning should be able to produce a community order which glorifies social prestige as a result of wealth and prosperity he experienced (Prihantoro, 2002).

There are three principles in multicultural education stated by Tilaar. First, multicultural education based on equity pedagogy. Second, multicultural learning is intended for the realization of smart Indonesian people and improvement of Indonesian individuals who understand knowledge as well as possible. Third, the principle of globalization is not to be feared as the nation recognizes the values and direction it brings whether it is good or bad (Tilaar, 2014).

The era of globalization brings very diverse impacts, especially in the field of education. Anticipating this, educators must understand the concept of multicultural education and be able to implement it in the learning process. So that the educator's perspective on the object of learning (students) is formed, that students must be placed as local and global citizens, not just as individuals. Islam introduces the concept of multicultural education through the paradigm that Allah SWT created humans with a variety of diversity, both from gender, ethnicity, skin color, and different cultural backgrounds. But all these differences have no effect in the sight of Allah SWT, because the glory in the sight of Allah SWT is very dependent on how many good deeds have been done by an individual.

Ainul Yakin explained that the initial goal of multicultural education was to apply the concept in the world of education in Indonesia, so that it was not just theory and discourse. If all education practitioners can grow multicultural awareness, it is hoped that they can also become agents of change. Multicultural education practitioners not only provide students with subject matter, but more than that, they are able to instill pluralist, humanist, and democratic values in students. To achieve optimal ability in instilling these values, multicultural education practitioners are required to understand and master all materials 
related to multicultural education well, even more so, they must be able to build democratic, pluralist and humanist characters in managed educational environments/institutions. This, according to Ainul Yakin, is the ultimate goal of multicultural education (Yakin, 2005).

The school also does not require female non-Muslim students to wear the hijab when at school. it is a form of tolerance for non-Muslim students. Students who are Muslim are also encouraged to respect students who do not wear the hijab. James Banks defined Multicultural Education as education for People of Color, which means that multicultural education wants to overcome differences in race and skin color as an unavoidable necessity, because race and skin color are gifts from God and sunnatullah (Mahfud, 2016).

This is in accordance with Burgess' statement that introducing tolerance can be implemented in children at early age. It is in line with the research result indicating that at the age of 3 years old, a child generally has tendency to be more inclined/easy to communicate with people who have elements in common with them. When 4-5 years old children are able to recognize social characteristics through skin color, which shows that there is a possibility of forming stereotypes in certain groups in their environment (Patnani, 2012).

The school also does not require non-Muslim students to take part in the religious activities of Muslim students at the school. Non-Muslim students are free to participate in religious celebration activities for Muslim students or not, but many non-Muslim students also participate in Muslim students' religious activities. According to Zakiyyudin Baidhawi, multicultural education is an effort to convey the concept of diversity through education (Zakiyuddin \& Baidhawi, 2007).

Multicultural education which is clearly seen in the lessons of Religion Education. In Religion learning, schools have special programs for non-Muslim students and religious learning according to their religion; Muslim students study Islamic religious education, while non-Muslim students get religious subject matter according to their religion, and they are free to take religious lessons that in their house of worship. Hanafy also conveyed the same thing, multicultural material can be integrated into the curriculum by integrating it into the learning process in each subject (Hanafy, 2015). 
The application of multicultural education through the learning process can be done through a process of habituation, until awareness of nationalism emerges. Awareness of nationalism in question is being aware of and feeling proud of the nation, being independent and brave in the nation, aware of honor as a nation, aware of fighting colonialism, aware of making sacrifices for the sake of the nation, awareness of nationalism of other nations, and aware of the regional elements possessed towards sense of nationality. The development of multicultural characters is the basis for the formation of the characteristics of Indonesian people with various ethnic, cultural, and linguistic diversity. This strength makes Indonesia a great nation that is built from the uniqueness and diversity of its ethnicity, culture, language and even religion in the midst of the arena of nations in the world (Najmina, 2018).

According to Sutarno, some important things that need to be considered by educators in the process of integrating multicultural values into learning are:

a. Every student has an opportunity to reach his or her optimal potential.

b. Understand how to learn and think critically.

c. Motivate students to play an active role in education process by reflecting on stories and experiences of their life into the learning scope.

d. Introduce various learning style to the students.

e. Make the students understand about the importance of respecting other groups who give contribution on our knowledge base.

f. Instill awareness of positive attitudes towards groups and individuals who are different from themselves.

g. Instill in students to become students, community members, citizens and the world community, as good citizens.

h. Teaches how to evaluate knowledge from different perspectives.

i. Develop local, national, and global identities.

j. Introduce skills when making decisions and critical analysis skills so that students can make the best choices in their daily lives (Sutarno, 2008). 
Meanwhile, according to Gordon and Robert, as quoted by Sutarno, the principles that need to be considered in the selection of subject matter in the implementation of multicultural learning are:

a. The discussion on the subject matter should cover matters related to multiculturalism, based on contemporary science.

b. The subject matter should represent plurality, diversity and unity across groups.

c. The selected subject matter should be in the context of time and place.

d. The selected subject matter should give priority to deepening, in addition to flexibility.

e. Multicultural perspectives should be included in the overall scope of the curriculum.

f. The selected subject matter should be treated as a social construct so that it is tentative like the whole knowledge.

g. The subject matter should be a picture composed based on the experience and knowledge experienced by students to be applied in classroom learning (Sutarno, 2008).

Pedagogy should be related to several interactive learning ways to improve understanding, contra version test, and mutual learning.

\section{CONCLUSION}

State Elementary School 2 Komet Banjarbaru implements multicultural education in order to foster students' tolerance through the equalization of each student's rights, no obligation for non-Muslim female students to wear hijab, no obligation for non-Muslim students to participate in Muslim students' activities, and special programs for non- students in term of religion studies in which students have their own religious learning according to their religion: Muslim students study Islamic religious education and non-Muslim students get religious subject matter according to their religion, and they are free to follow religious lessons in their houses of worship. 


\section{REFERENCES}

Ahsani, E. L. F., \& Azizah, N. R. (2021). Implementasi Literasi Budaya dan Kewargaan untuk Mengembangkan Keterampilan SosialSiswa Madrasah Ibtidaiyah di Tengah Pandemi. Jurnal Pendidikan Kewarganegaraan, 11(01), 7-16. https://doi.org/http://dx.doi.org/10.20527/kewarganegaraan. v11i01.10317

Al-makasasary, R., \& Suparto. (2010). Cerita Sukses Pendidikan Multikultural di Indonesia. Center for Study of Religion and Culture.

Amin, M. (2018). Pendidikan Multikultural. 9(1), 11.

Arifudin, I. (2007). Urgensi Implementasi Pendidikan Multikultural di Sekolah. 12(2), 79.

Baharun, H., \& Awwaliyah, R. (2017). Pendidikan Multikultural dalam Menanggulangi Narasi Islamisme di Indonesia. Jurnal Pendidikan Agama Islam (Journal of Islamic Education Studies), 5(2), 224. https://doi. org/10.15642/jpai.2017.5.2.224-243

Dewi, I. R., Marini, A., \& Maksum, A. (2020). Problematika Implementasi Pendidikan Multikultural.3(2), 7.

Faiqoh, N. (2015). Implementasi Pendidikan Berbasis Multikultural Sebagai Upaya Penguatan Nilai Karakter Kejujuran, Toleransi, Dan Cinta Damai Pada Anak Usia Dini Di Kiddy Care. Universitas Negeri Semarang.

Furqon, M. (2020). Pendidikan Multikultural dalam Dunia Pendidikan di Indonesia. $1(1), 12$.

Hanafy, M. S. (2015). Pendidikan Multikultural dan Dinamika Ruang Kebangsaan. 3(1), 21.

Ibrahim, R. (2013). Pendidikan Multikultural: Pengertian, Prinsip, dan Relevansinya dengan Tujuan Pendidikan Islam. 7(1), 33.

Kholik, N. (2017). Peranan Sekolah Sebagai Lembaga Pengembangan Pendidikan Multikultural. 1(2), 19.

Mahfud, C. (2016). Pendidikan Multikultural. Pustaka Pelajar. 
Mansur, R. (2016). Pengembangan Kurikulum Pendidikan Agama Islam Multikultural (Suatu Prinsip-orinsip Perkembangan). 10(2), 4.

Moleong, L. J. (2012). Moleong, L. J. (2012). Metodologi penelitian Kualitatif (Revisi). Rosdakarya.

Munajah, R., Marini, A., \& Maksum, A. (2020). Persepsi Guru tentang Pelaksanaan Pendidikan Multikultural di Sekolah Dasar Negeri 13 Pandeglang. 3(2), 6.

Najmina, N. (2018). Pendidikan Multikultural Dalam Membentuk Karakter Bangsa Indonesia. 10(1), 5.

Nurcahyono, O. H. (2018). Pendidikan Multikultural Di Indonesia: Analisis Sinkronis Dan Diakronis. Habitus: Jurnal Pendidikan, Sosiologi, $\mathcal{E}$ Antropologi, 2(1), 105. https:/ / doi.org/10.20961/habitus.v2i1.20404

Patnani, M. (2012). Pengajaran Nilai Toleransi Usia 4-6 Tahun. 1(1), 132.

Prihantoro, A. (2002). Politik Pendidikan: Kebudayaan, kekuasaan dan Pembebasan. Yogyakarta: Pustaka Pelajar. Pustaka Pelajar.

Rahayuningtyas, D. R., Rizqi, P. A., Putri, R. F. M., Sawwama, A., \& Ahsani, E. L. F. (2021). Peran Guru Dalam Mempertahankan Cultural Heritage Indonesia Dalam Membentuk Karakter Siswa di Sekolah Indonesia Kuala Lumpur. PENSA : Jurnal Pendidikan Dan Ilmu Sosial, 3(April), 2737. https:/ / doi.org/https://doi.org/10.36088/pensa.v3i1.1126

Sujarwanto, I. (2012). Interaksi Sosial Antar Umat Beragama (Studi Kasus pada Masyarakat Karangmalang Kedungbanteng Kabupaten Tegal. 1(2), 5.

Suprapti, R. (2018). Suprapti, R. (2018). Implementasi Pendidikan Multikultural di SD Negeri Paliyan I Gunungkidul. Uniersitas Islam Indonesia.

Sutarno. (2008). Pendidikan Multikultural. Tinggi Departemen Pendidikan Nasional.

Syakrani. (2020, January 20). Pendidikan Multikultural [Personal communication].

Tilaar, H. R. (2014). Multikulturalisme: Tantangan-Tantangan Global Masa Depan Dalam Transformasi Pendidikan. Grasindo.

Yakin, A. (2005). Pendidikan Multikultural Cross Cultural Understanding untuk Demokrasi dan Keadilan. Pilar Media. 
Barsihanor, Abdul Hafiz, Muhammad Iqbal Ansari et al.

Zakiyuddin, \& Baidhawi. (2007). Pendidikan Agama Berwawasan Multikultural. Erlangga. 